\title{
Cylindrocladium quinqueseptatum leaf and twig blight of Eucalyptus species.
}

\author{
Nishu Chaudhary
}

\begin{abstract}
Cylendrocladium quinqueseptatum, a soil born pathogen, cause leaf and twig blight disease in nurseries and plantation of Eucalyptus often aggravates during monsoon season to epidemic proportions resulting in large scale mortality of young seedling in nurseries and extensive defoliation of young plants and young coppice shoots in plantations. CLB caused by Cylindrocladium quinqueseptatum was first serious disease to be reported by Sehgal et al.,(1969) that affected Eucalyptus seedlings in nurseries and plantation. Cylindrocladium is known to cause foliage as well as root diseases of Eucalyptus in Kerala (Sharma et al. 1984). Different diseases of this pathogen has been reported to cause Eucalyptus diseases in south India. However, in northern part of India only one species, Cylendrocladium quinqueseptatum is encountered causing seedling blight in Eucalyptus nurseries.
\end{abstract}

Keywords: Cylendrocladium quinqueseptatum, Cylindrocladium leaf blight, Eucalyptus, Fungicide.

\section{Introduction}

Large scale seedling mortality in Eucalyptus nurseries of North Indian states caused by Cylendrocladium quinueseptatum has posed serious threat to paper and pulp industries of this region fearing decline in production, as majority of industry-sponsored nurseries raised by local farmers for achieving the plantation targets have witnessed this disease in epipytotic proportions in the resent years. Worst affected North Indian states are Uttarakhand, Punjab and Haryana. Losses from Cylendrocladium quinqueseptatum seedling blight is due to out right killing of the entire seedling within a couple of weeks time during monsoon season and blightning of leaves in plantations thus adversely affecting the tree growth. Severe mortality has been recorded in nurseries and plantations in Uttarakhand, Punjab, Haryana and U.P. Cultural practice to avoid the disease incidence is often ineffective as the pathogen over winters in soil and with the every passing year the inoculum increases in geomatrical proportions. The only option left with the nursery Manager is to shift the nursery to a newer area.

In Kerala, Eucalyptus species have been raised in forest plantations to meet the raw material demands of the pulp and paper industries in the state; so far, about 38000 have been planted with E. Grandis and E. Tereticornis (Karunakaran, 1982). When large scale plantation of eucalyptus began during the early 1960s, apparently there was not much serious disease problem encountered by CLB. A few years later, became a severe problem in raising healthy nurseries, accounting for up to almost $100 \%$ seedling mortality, in seedbeds and containers in high rainfall areas during the monsoon. Besides, stocking in nurseries is affected due to dampingoff caused by C. quinqueceptatum, C. ilicicola, C. floridanum and C. parvum, and seedling blight caused by C. quinqueseptatum, C. ilicola, C. parvum, C. camelliae, C. curvatum and C. scoparium. Cylindrocladium sp. Are widespread and damping pathogens of a very wide range of plant hosts including eucalyptus. Crous, (2002) has distinguised 39 Cylindrocladium sp. of these 24 are listed as pathogens of Eucalyptus sp. and 15 of these have been found in South-East Asia. Probably eucalyptus is the only host which is attacked by at least $10 \mathrm{sp}$. of Cylindrocladium in Kerala (Sharma and Mohanan 1982; Sharma et al., 1984; Mohnan and Sharma 1984, 85; Nair and Jayasree 1986).

In the North Central and Northeastern States and in the Province of Ontario, species most commonly affected include red and eastern white pines, along with black and white spruces. In the Southern States, seedlings of black walnut, yellow poplar, sweetgum, eucalyptus and eastern white pine are the most commonly affected. Infection by species of C. quinqueseptatum can result in a variety of symptoms. These include pre and post emergence damping off, root rot, foliage blight and stem lesioons. Leaf and shoot blight, which develop upwards from the base of trees occur in young trees.

The most common and severa causal agent of Cylindrocladium leaf blight in South-East Asia is C. reteaudii (Bugn) Boesew. (syn. C. quinqueseptatum Boedijn and reitsma), which is responsible for epidemic disease in several countries including Australia, India, Vietnam, Laos and parts of Thailand. The disease first shows as grayish water-soaked spots on young leaves. These spots coalesce and develop in to extensive necrotic areas. Large numbers of shining white spores can be seen at the margins of lesions, on older necrotic portion of leaves, especially along midribs on the abaxial surfaces, and on fine shoots. Under favourable conditions of high humidity and frequent rainfall, necrotic lesion cover the entire area of the leaf and fruit profusely on young 
shoot tips which are killed, resulting in leaf and shoot tips which are killed, result in leaf and shoot blight symptoms (Bolland et al. 1985)

CLB can be controlled effectively and economically in nurseries using prophylactic fungicidal treatment ( Anon 1984) but chemical control of CLB in plantation is considered prohibititively expensive and impractical. A preception of these chemicals as a threat to human health and the environment is leading to increasingly straight laws limiting their use and swaying government policies toward the use of biological control measures in plant protection. There are three basic approches of disease control available to nurseries: Culture control, which involves changes in the growing conditions and culture practices. Chemical control, which involves selective chemicals that kill or inactivate the pathogen but do little or no harm to the host seedlings. Biological control in which an antagonistic is used to control the disease.

Chemical control may be used to protect the seedling or eradicate the pathogen. Soil drenching or spraying with a fungicide, for a instance, protests seedling by coating the vulnerable plant surface with a chemical barrier that is toxic to pathogens. Such chemicals control requires proper timing to coincide with periods of infection. Soil fumigation prior to planting can effectively control root disease pathogens but seldom completely eradicate them. An important aspect of the sporulation is the ability of Tricoderma to produce toxin such as tricodermin, viridin etc. Various species of Tricoderma were extensively tested against seed borne disease and have proved successful in controlling Rhizoctonia sp., Pythium sp., Sclerotium sp. and Cylindrocladium quinqueseptatum (Papavizas, 1985).

\section{Chemical control}

\section{Materials and Methods}

Poison food technique was used to evaluate fungicides against Cylindrocladium quinqueseptatum. The principle involve in this technique is to poison the nutrient medium with fungi toxicant and then allowing a test fungus to grow on such medium. The fungicides was incorporated in a medium in requisite quantity so as to give a certain concentration and thoroughly mixed by constant stirring. The medium was then poured into culture plates and allow to solidify. A disc of $9 \mathrm{~mm}$ of 7 days old Cylindrocladium quinqueseptatum culture growing on potato dextrose agar (PDA) medium was then cut with a sterile cork. The plates were inoculated with the disc and incubated $22^{\circ} \mathrm{C}$ temperature for the growth of test fungus.

\section{Systemic and non systemic fungicides used}

Thiram (Thiram 75\% W. p.), Baylaton (Triadimefon 25\% W. p.), Dithane M-45 ( Mancozeb $75 \%$ W. p.), Ridomil (Metalaxyl, Mancozeb 72\% W. p.), Bavistin (Carbendazim 50\% W. p.), Benlate (Benomyl 50\% W.p.).

\section{Dispensing media into culture plates and inoculation}

$0.05 \%, 0.2 \%$ and $0.1 \%$ concentration of each fungicide were taken. Under aseptic conditions, fungicides were added into the sterilrilized medium and mixed well. Medium was then poured into the sterilized culture plates and allowed to solidify. It was then inoculated with Cylindrocladium quinqueseptatum culture as according to poison food technique. Culture plates were incubated at $22^{\circ} \mathrm{C}$ and observations were taken every 48 hours for six days.

\section{Biological control}

The microorganism used as biological control agents were Trichoderma virens, Trichoderma harzianum, Trichoderma album, Trichoderma koningii, Trichoderma viride and Pseudomonas fluorescens. In this method the medium was seeded by Cylindrocladium quinqueseptatum on one end of the culture plate while the biocontrol agent on the opposite sides of the plates. The growth of Cylindrocladium quinqueseptatum against the biocontrol agent was monitored for 10 days.

\section{Selection of fungal antagonists}

Trichoderma virens is known for its antagonistic activity towards Rhizoctonia sp. Trichoderma is a saprophytic soil fungi, widely distributed all over the world and occurs nearly in all soils and other habitats. Several antifungal metabolites are known to be produced by Trichoderma sp. such as Trichodermin, virens.(Ghaffar and Ghaffar 1988). Trichoderma is known for its antagonistic activity towards Cylindrocladium quinqueseptatum. (Papavizas, 1985). The interaction of Trichoderma with its host is specific.( Chet and Baker, 1981; Elad et al., 1980; Siven et al., 1984).

\section{Biculture test ( Dual culture test)}

For testing the antagonistic properties of microorganism obtain from different locations were screened under invitro conditions against the pathogen, using "biculture test" ( Dhingra and Sinclair, 1995). Detailed 
methodology is as below: PDA was used as culture media. Media was autoclaved for sterilization. Autoclaved media was poured into the culture plates. After the medium was solidified it was seeded with biocontrol species and Cylindrocladium quinqueseptatum on two opposite sides of the culture plates in aseptic condition. The plates were incubated at $22^{\circ} \mathrm{C}$ and observed for the growth of Cylindrocladium quinqueseptqtum and test microbes. Intraction of antagonism was assayed using a key based on the observation of Skidmore and Dickson (1976) who recognized five separate mode of interacting colony growth.

1. Grade A- Homogeneous: Free intermingling between pairing organism.

2. Grade B- Mycoparasitism: Fungus feeding upon another fungus.

3. Grade C- Overlapping growth: Where antagonist overlapped the opposite partner.

4. Grade D- Checking the growth at line of contact: Two organism grew towards each other but growth stopped at the common margin.

5. Grade E- Aversion: A clear zone of inhibition between the two organisms at a distance of more than $2 \mathrm{~mm}$.

Type of antagonism:

Grade A- Homogeneous

Grade B- Mycoparasitism

Grade C- Overlapping

Grade D- Inhibition at line of contact

Grade E- Distinct antagonism

\section{Result and Discussion}

Chemical control: By employing poison food technique various dosages of different fungicides were screened. Table 1 reveal that.

Table 1: Colony growth of Cylindrocladium quinqueseptatum in different dose of fungicides.

\begin{tabular}{|l|l|l|l|l|}
\hline Treatment & \multicolumn{4}{|c|}{ Colony growth in different doses of fungicides } \\
\hline Bavistin & & $0.1 \%$ & $0.2 \%$ & $0.5 \%$ \\
\cline { 2 - 5 } Thram & 0 & 0 & 0 & 0 \\
Ridomil & 0 & 0 & 0 & 0 \\
Bayleton & $7.00 \mathrm{~cm}$ & $6.99 \mathrm{~cm}$ & $6.74 \mathrm{~cm}$ & $6.74 \mathrm{~cm}$ \\
Mancozeb & $3.24 \mathrm{~cm}$ & $2.10 \mathrm{~cm}$ & $2.28 \mathrm{~cm}$ & $2.28 \mathrm{~cm}$ \\
$\begin{array}{l}\text { Copper } \\
\text { oxy-chloride }\end{array}$ & $6.70 \mathrm{~cm}$ & $6.53 \mathrm{~cm}$ & $6.54 \mathrm{~cm}$ & $6.54 \mathrm{~cm}$ \\
\hline
\end{tabular}

No growth was in all the dosage of Bavistin, benlate and thiram fungicidal effect irrespective of dosage placed bavistin, benlate and thiram at par. These are most effective fungicides followed by Bayleton and copper oxy-chloride. No colony inhibition was found in mancozeb and ridomil. Even after 10 days of inoculation no growth was observed in bavistin, benlate and thiram but in bayleton colony growth was restricted to some extent. While in copper oxy-chloride growth was observed more than bayleton. The lowest concentration of bavistin, benelate and thiram did not show any trace of colony growth of Cylindrocladium quinqueseptatum, so it was clear that these three fungicides are most effective than others tested in this experiment. High effectiveness of benlate, thiram and bavistin in inhibiting Cylindrocladium species is well supported by previous workers. Sen and Kapoor (1974) reported control of wilt of pea caused by F. oxysporium species by seed treatment with carbendazim at $0.2 \%$. Patil (1980) reported control of many fungi like Penecillium sp., Alternaria alternate and Rhizoctonia by carbendazim. Copper oxy-chloride showed some inhibition in colony growth but was not completely effective. This may be due to the presence of low soluble of copper. As stated by Nene and Thapliyal (1982) that in this compound copper was stabilized and rendered less soluble, which considerably reduced the phytotoxic properties of copper. IT is concluded from the study that while using systemic fungicides benlate or bavistin at $0.05 \%$ dosage should be preferred to control Cylindrocladium quinqueseptatum blight disease. However, looking into the economic bavistin is more cost effective. Mancozeb and ridomil do not effectively inhibit pathogen colony growth even at concentration as high as $0.2 \%$ and hence can not be used for the chemical control of Cylindrocladium quinqueseptatum.

Biological control: The microorganism used for the study were identified by using standard keys, viz: Gilman (1957), Bissett (1984, 1991 and 1992) and Rifai's (1969) research paper. In this study species of Trichoderma such as T. virens, T. viride, T. harzianum, T. album, T. koningii for the biological control of Cylindrocladium quinqueseptatum. The following table showed the behavior of C. quinqueseptatum in response to the species of Trichoderma sp. 
Table 2: Interaction of Cylindrocladium quinqueseptatum with Trichoderma species after 10 days growth.

\begin{tabular}{|c|c|c|c|c|c|}
\hline Grade & Homogeneous & Mycoparasitism & Overlapping & $\begin{array}{l}\text { Inhibition at } \\
\text { Line of contact }\end{array}$ & Aversion \\
\hline T.harzianum & - & - & $\sqrt{ }$ & - & - \\
\hline T. koningii & - & - & $\sqrt{ }$ & - & - \\
\hline T. virens & - & - & $\sqrt{ }$ & - & - \\
\hline T. viride & - & - & - & - & - \\
\hline T. album & - & - & $\sqrt{ }$ & - & - \\
\hline $\begin{array}{l}\text { Psuedomonas } \\
\text { flourescens }\end{array}$ & - & - & - & $\sqrt{ }$ & - \\
\hline
\end{tabular}

The biological control experiments revealed that all the fungi viz T. virens, T. album, T. harzianum and T. koningii were antagonistc to Cylindrocladium quinqueseptatum colony growth and inhibited its growth. T. virens showed aversion with Cylindrocladium quinqueseptatum leaving clear space between culture.

Saksirirat et al. (1996) observed that an integrated biological and chemical control could also be used against many diseases. He observed control of Sclerotium rolfsii on tomatoes by combining Trichoderma harzianum with the fungicide mancozeb. In view of above can conclude that systemic fungicides viz. benlate $(0.05 \%)$, thiram $(0.05 \%)$ and bavistin $(0.05 \%)$ are most effective against Cylindrocladium quinqueseptatum and render complete colony inhibition of Cylindrocladium quinqueseptatum.

Among the bio control agent though all the Trichoderma species inhibited colony growth, the quickest inhibition was provided by $\mathrm{T}$. koningii. Tricoderma is a non pathogenic fungi and provide very quick and effective inhibition of pathogen colony. Hence benlate, bavistin, thiram and T. koningii should be preferred for the disease management and further glass house and nursery studies are needed to conclude their effectiveness in field conditions.

\section{References}

[1]. Anonymus (1984). Nursery diseases of Eucalyptus in Kerala and there possible control measures. Kerala forest research institute information bulletin no. 6:16.

[2]. Baker, R. and Dickman, M.B. (1992). Biological control with fungi. In Soil microbial ecology: applications in agricultural and environment management (ed. F. Blaine Metting Jr.). pp.275-305.

[3]. Boesewinkel, H.J. (1982). Cylindrocladiella, a new genus to accommodate Cylindrocladium parvum and other small-spored species of Cylindrocladium. Can.J.Bot.60:2288-2294.

[4]. Bolland, L., Tierney, J.W. and Tierney, B.J. (1985). Studies on leaf spot and shoot blight of Eucalyptus caused by Cylindrocladium quinqueseptatum. European journal of forest patholy. 15:385-397.

[5]. Chet, I. and Henis, T. (1985). Tricoderma as biocontrol agent against soil borne root pathogens. In ecology and management of soilborne plant pathogens (eds. Parker, C.A., Rovira, A.D., Moore, K.J., Wonger, P.T.W. and Kollmorgen, J.F.). pp.110-112. 